\title{
IMPACT OF DIETARY SUPPLEMENTATION OF MILK THISTLE (Silybum marianum) SEED EXTRACT ON DOE RABBITS PERFORMANCE
}

\author{
Amira M. Refaie, Mervat N. Ghazal, Enayat H. Abo El-Azayem and Marwa H. Abd El- \\ maged
}

Animal Production Research Institute, ARC, Dokki, Giza, 12618, Egypt

Corresponding author: amera.refay@arc.sci.eg

(Received 18/6/2019, accepted 30/7/2019)

\section{SUMMARY}

$\mathrm{M}$

ilk thistle seed extract consists mainly of flavonolignans, which include silybin (silibinin), sylichrisitn, and silydianin that commonly referred to Silymarin. A total number of thirty six, 9-10 month old New-Zealand white muliparous does, with an average weight of $3641 \mathrm{~g} \pm$ 94.02 were used to evaluate the response to dietary supplementation with ethanolic milk thistle extract (MTE) containing $70 \%$ silymarin on some performance aspects during pregnancy and lactation periods. Does were allocated to 4 experimental groups, 9 does of each. Rabbits were fed the experimental diets started one month before first mating. Does were allowed to the following treatments; a control group was fed a basal diet without MTE (T1), then the $2^{\text {nd }}, 3^{\text {rd }}$, and $4^{\text {th }}$ were fed the basal diet supplemented with $3 \mathrm{ml}, 6 \mathrm{ml}$ or $9 \mathrm{ml}$ MTE/kg diet, respectively and abbreviated as 3MTE (T2), 6MTE (T3) and 9MTE (T4), respectively. The trail was ended after pregnant period and nursering kits till weaning. The results indicate that feed intake during pregnancy (except T2) and lactation, litter weight at birth and weaning (except T2) were significantly $(\mathrm{P} \leq 0.05)$ increased by supplementing does diets with MTE at 6 or $9 \mathrm{ml} / \mathrm{kg}$ diet compared to the control. Also, litter size at birth and litter size at weaning (except $\mathrm{T} 2$ ) were significantly $(\mathrm{P} \leq 0.05)$ higher with MTE supplementation compared to the control. Milk production significantly $(\mathrm{P} \leq 0.05)$ was the highest in 9MTE group for the first four weeks compared with the control. Plasma prolactin hormone was significantly $(\mathrm{P} \leq 0.05)$ improved gradually by enriched does diet with MTE, but liver enyzmes (AST \& ALT) was insignificantly higher in all MTE groups compared to the control. It could be concluded that adding milk thistle seed extract to does diets enhanced their performance during gestation and lactation periods, in term of increased their milk production and litter weight at birth and weaning.

Keywords: Milk thistle extract, doe rabbits, milk production and prolactin.

\section{INTRODUCTION}

Rabbit does are in general allowed to nurse their kits till weaning age (4-5 weeks of age). Kits until 18-19 days of age exclusively depending on the milk of their mother (Fortun-Lamothe et al., 2000). Newborn rabbits have high energy requirements and a low thermal isolation. Therefore early livability and growth performances are closely related to the quantity and quality of the milk ingested (Szendrö and Maertens, 2001). Consequently, demands and requirements of does for milk yield have increased greatly. However, strains were primarily successfully selected for increased litter size with lower weight of kits (Rochambeau, 1998). This indicates that the relative increase of milk yield was smaller than that of litter size, leading to smaller amounts of milk available per kit (Szendrö and Maertens, 2001).

Studies have shown that milk yield of doe rabbits are strongly influenced by diet composition (Maertens et al., 2006 and Pascual et al., 2002). Milk thistle (Silybum marianum L.) contains silymarin which is a mixture of flavonolignans, mainly silibinin (also known as silybin). It has been widely studied for its hepatoprotective (Giese, 2001), anti-inflammatory (Gupta et al., 2000), antioxidant and choleric properties (Nencini et al., 2007), but silymarin is also used in alternative medicine to increase milk yield 


\section{Refaie et al.}

in women with hypogalactia (Di Pierro et al., 2008). Such a beneficial effect was also seen in domestic species, as silymarin increased milk production in cows (Tedesco et al., 2004). Silymarin is a standardized preparation extracted from the fruits (seeds) of milk thistle. Milk thistle is a purported galactogogue (Jackson,2010). Some studies show that herbal galactagogues can increase breast milk production (Forinash et al.,2012, Zapantis et al. 2012 and Mortel and Mehta 2013). Studies using animal models showed that extracts of herbal galactagogues, such as Silitidil which is a standardized extract of milk thistle and Silymarin BIO-C which is an extract from Silybum marianum fruits, increased serum prolactin levels significantly in female rats and that this appears to be the mode by which milk production is increased (Capasso et al. 2009, and Capasso 2014). This study aims to evaluate the effect of graded levels of milk thistle seed extract on performance of pregnant and lactating doe rabbits and their off-springup to weaning.

\section{MATERIALS AND METHODS}

The experimental work was carried out at Sakha Animal Production Research Station, Animal Production Research Institute, Agricultural Research Center, Ministry of Agriculture, Dokki, Giza, Egypt.

\section{Preparations of milk thistle extract (MTE):}

A sample of $500 \mathrm{~g}$ of Silybum marianum seed powder was placed in a thimble made of filter paper and inserted into the wide central tube of the extractor of the Soxhlet apparatus. The solvent (ethanol 95\%) was placed in the flask and heated at $78{ }^{\circ} \mathrm{C}$ and their vapor was condensed in a reflux condenser. The condensed extract was dripped into the thimble containing the crude component, which was extracted by contact. When the level of the liquid in the chamber had risen to the top of the siphon tube, the liquid contents of the chamber was drained off into the flask. This process was continued until a drop of the solvent from the siphon tube did not leave any residue when evaporated (Handa, 2008). The extract was stored in a refrigerator $\left(4{ }^{\circ} \mathrm{C}\right)$ until used and was mixed with feed before pelleting. Active component of the extract was analyzed according to Cai et al. (2009), which contains approximately $70 \%$ determined silymarin.

\section{Experimental animals, design and management:}

Thirty six multi-parious New Zealand White does 9-10 months old weighing 3641g \pm 94.02 were equally allocated to four groups as follows:

T1 (control): fed basal diet without supplementation.

T2: fed basal diet $+3 \mathrm{ml} \mathrm{MTE} / \mathrm{kg} \operatorname{diet}(3 \mathrm{MTE})$.

T3: fed basal diet $+6 \mathrm{ml} \mathrm{MTE} / \mathrm{kg} \operatorname{diet}(6 \mathrm{MTE})$.

T4: fed basal diet $+9 \mathrm{ml}$ MTE/kg diet (9MTE).

Each group had 9 does, which were fed the experimental diets for one month before first mating. Detection of conception was carried out by palpation at 10 days after mating and the non pregnant were re-mated immediately. Does were housed in individual wired-cages. All animals were kept under the same management and hygienic conditions and provided with fresh water and pelleted diets ad-libtum over the experimental period.

\section{Experimental diets and measurements:}

Diets were formulated to meet the Agriculture ministry decree (1996) requirements during pregnancy and lactation periods. Ingredients and calculated analyses of the basal diet are presented in Table (1). Variables of does weight, doe feed intake, litter size and weight at birth and at weaning were considred. Individual blood samples were collected from three does of each treatment from the marginal ear vein in $5 \mathrm{ml}$ heparinized test tubes and centrifuged at 3000 r.p.m for 20 minutes then plasma were stored at $-20^{\circ} \mathrm{C}$ until analysis for aspartate amino-transferase, AST, alanine amino-transferase, ALT ( Biosystems, S.A., Spain) according to Reitman and Frankel (1957) and prolactin levels (ELISA kit (ABO Swiss Co., Ltd, China) according to Kletzky et al. (1980). 
Table (1): Ingredients and calculated analysis of the basal diet.

\begin{tabular}{|c|c|c|c|}
\hline Ingredient & $\%$ & Calculated chemical analysis & \\
\hline Barley & 17.5 & Crude protein $(\%)$ & 18.26 \\
\hline Wheat bran & 32.2 & Digestible energy (kcal/kg) & 2620 \\
\hline Soybean meal (44\%) & 13.6 & Crude fiber $(\%)$ & 11.14 \\
\hline Clover hay $(12 \%)$ & 17.9 & Ether extract (\%) & 2.75 \\
\hline Corn gluten $(60 \%)$ & 3.5 & Calcium $(\%)$ & 1.23 \\
\hline Yellow corn & 11.5 & Total phosphorus (\%) & 0.81 \\
\hline Limestone & 1.5 & Lysine $(\%)$ & 0.82 \\
\hline di-Calcium phosphate & 1.5 & Methionine (\%) & 0.51 \\
\hline $\mathrm{NaCl}$ & 0.3 & Methionine + cystein & 0.84 \\
\hline Vitamins and menial premix* & 0.3 & Sodium & 0.16 \\
\hline Dl- Methionine & 0.2 & & \\
\hline Total & 100 & & \\
\hline
\end{tabular}

\section{Milk production and composition:}

Milk production was estimated by using doe-suckle-weigh method (Lukefahr et al., 1983). Milk samples were drawn on d 21 after parturition. Milk composition was evaluated for total lipid, total protein, and albumin content by infrared analyzer with a Milkoscan (Milk-o-Scan 605, Foss Electric, Hillerd, Denmark) according to the method of El-Sayiad et al. (1994). While, globulin was calculated by subtracting albumin from total protein and $\mathrm{A} / \mathrm{G}$ ratio was also calculated.

\section{Statistical analysis:}

The obtained data were statistically analyzed using one-way analysis of variance procedure (SAS, 2001) computer program using the following model:

$$
\mathrm{Y}_{\mathrm{ij}}=\mu+\mathrm{T}_{\mathrm{i}}+\mathrm{e}_{\mathrm{ij}}
$$

Where $Y_{i j}=$ the individual observation. $\mu=$ overall mean, $T_{i}=$ effect of treatments $(i=1,2,3$ and 4$)$. $e_{i j}=$ random error.

Significant differences between treatments means were determined at $(\mathrm{P} \leq 0.05)$ and $(\mathrm{P} \leq 0.01)$ by Duncans multiple-range test (Duncan's, 1955).

\section{RESULTS AND DISCUSSION}

Results in Table (2) show that the highest pregnant does feed intake was observed in T4 (fed 9MTE) without significant difference to those of T3 (fed 6MTE), while the lowest consumption of feed was recorded for T2 (fed 3MTE) without significant differences to control (T1). This finding may be due to improve the palatability of the diet by increasing MTE level. These results disagree with the findings of Attia et al. (2017) who concluded that feeding rabbit bucks with dietary ground milk thistle seeds reduced their feed intake compared to the control group. All of the tested groups recorded significantly higher litter size by $15.4 \%, 28.2 \%$ and $20.5 \%$, respectively compared to control group. The improvement in these groups might be due to improving the ovulation rate in does fed MTE compared to control as reported by Taher et al. (2012) who found that treated women with silymarin (750mg/day) enhanced their ovulation rate by incrementing progesterone hormone levels. Group of 6MTE and 9MTE achieved significantly higher litter weight compared to control and 3MTE groups. These results confirm the latest research of Mohammad et al. (2019) who documented that feeding female rat with $200 \mathrm{mg} \backslash \mathrm{kg} \backslash \mathrm{day}$ of milk thistle extract resulted in higher litter weight at birth compared to control. 
Refaie et al.

Table (2): Effect of different levels of milk thistle seeds extract on does performance during gestation period.

\begin{tabular}{|c|c|c|c|c|c|c|}
\hline Item & T1 & $\mathrm{T} 2$ & T3 & $\mathrm{T} 4$ & $\pm \mathrm{SE}$ & Sig. \\
\hline Mating weight (g) & 3756 & 3694 & 3641 & 3699 & 94.02 & $\mathrm{NS}$ \\
\hline Feed intake $(\mathrm{g})$ & $4264^{b c}$ & $4193^{c}$ & $4824^{\mathrm{ab}}$ & $5086^{\mathrm{a}}$ & 193 & $*$ \\
\hline Live litter size at birth & $5.57^{\mathrm{b}}$ & $6.43^{\mathrm{a}}$ & $7.14^{\mathrm{a}}$ & $6.71^{\mathrm{a}}$ & 0.24 & $*$ \\
\hline Litter weight at birth (g) & $262.14^{\mathrm{a}}$ & $271.43^{b}$ & $326.43^{\mathrm{a}}$ & $311.43^{\mathrm{a}}$ & 12.04 & $*$ \\
\hline
\end{tabular}

${ }^{a}, b$ and ${ }^{c}$ Means within the same column with different superscripts are significantly different,

$* P \leq 0.05, N S=$ non significant.

T1 (control), T2: fed basal diet $+3 \mathrm{ml}$ MTE (3MTE),

T3: fed basal diet + $6 \mathrm{ml}$ MTE (6MTE), T4: fed basal diet + $9 \mathrm{ml}$ MTE (9MTE).

According to milk production (Table 3), rabbits of T4 fed the highest level of MTE (9 ml) T4 group recorded significantly the best milk yield during the first 4 weeks after delivering bunnies, while at last week of lactation (fifth week) this improvement was disappeared. These results are in agreement with Mohammad et al. (2019) who reported that silymarin increased the activity of mammary gland and thus milk production in female rats. There are several reviews speculated that milk thistle seed stimulate milk production as tested in rats (Capasso et al., 2009) and dairy cow (Tedesco et al., 2004). This observation has gained a renewed interest in its galactogenic properties. Moreover, Silymarin reduced the negative conditions experienced in transition to metabolic adaptation at the beginning of lactation and thus improved the milk yields (Ulger et al., 2017).

Table (3): Effect of different levels of milk thistle seeds extract on does milk production during different weeks.

\begin{tabular}{|c|c|c|c|c|c|c|}
\hline \multirow[b]{2}{*}{ Item } & T1 & $\mathrm{T} 2$ & T3 & T4 & \multirow[b]{2}{*}{$\pm \mathrm{SE}$} & \multirow[b]{2}{*}{ Sig. } \\
\hline & \multicolumn{4}{|c|}{ Average milk production (ml/doe/day) } & & \\
\hline Week 1 & $43.3^{c}$ & $64.2^{b}$ & $68.6^{b}$ & $94.3^{\mathrm{a}}$ & 5.94 & $* *$ \\
\hline Week 2 & $95.8^{b}$ & $93.3^{b}$ & $131.7^{\mathrm{ab}}$ & $149.3^{a}$ & 13.6 & * \\
\hline Week 3 & $125.8^{\mathrm{c}}$ & $131.0^{\mathrm{c}}$ & $177.1^{b}$ & $249.3^{\mathrm{a}}$ & 14.7 & $* *$ \\
\hline Week 4 & $127.1^{\mathrm{b}}$ & $160.8^{a b}$ & $131.7^{b}$ & $192.9^{a}$ & 16.5 & $*$ \\
\hline Week 5 & 141.7 & 122.0 & 122.5 & 131.7 & 13.4 & NS \\
\hline
\end{tabular}

${ }^{a}, b$ and ${ }^{c}$ Means within the same column with different superscripts are significantly different,

$* P \leq 0.05, * * P \leq 0.01, N S=$ non significant .

T1 (control), T2: fed basal diet $+3 \mathrm{ml} M T E$ (3MTE),

T3: fed basal diet + $6 \mathrm{ml}$ MTE (6MTE), T4: fed basal diet + $9 \mathrm{ml}$ MTE (9MTE).

During lactation period (Table 4), it is worthy to note that by increasing the level of MT in does diet, feed intake was gradually $(\mathrm{P} \leq 0.05)$ increased compared to control. does fed either 6MTE (T3) or 9MTE (T4) recorded significantly higher weaning litter size by $41.2 \%$ and $29.4 \%$, respectively compared to control. This confirms the result of increasing milk yield in these groups. Moreover, silymarin (the active component of MTE) has antioxidant effect according to Kshirsagar et al. (2013) what cause a protective action against lipid oxidation in the cell membrane (Liebler, 1992). Also, it is important for newborns which exhibits a greater sensitivity to oxidative damage than adults, and for the development of the immune system in young animals (Debier et al., 2005). By increasing dietary MTE level from $6 \mathrm{ml}$ to $9 \mathrm{ml}$ in does diet, the weaning litter weight (5 weeks) was increased significantly by $15.5 \%$ and $28.8 \%$, respectively compared to untreated group. The improvement in weaning weight of bunnies may be due to increasing in milk yield as reported previously in Table (3). These results agree with Mohammad et al. (2019) who concluded that feeding silymarin in female rats improved significantly their litter weight as a result of increasing milk production. 
Table (4): Effect of different levels of milk thistle seeds extract on does performance during lactation period.

\begin{tabular}{|c|c|c|c|c|c|c|}
\hline Item & $\mathrm{T} 1$ & $\mathrm{~T} 2$ & $\mathrm{~T} 3$ & $\mathrm{~T} 4$ & $\pm \mathrm{SE}$ & Sig. \\
\hline Feed intake $(\mathrm{g})$ & $5757^{b}$ & $6820^{a}$ & $6927^{a}$ & $7043^{a}$ & 23.7 & $*$ \\
\hline Live litter size at weaning & $4.86^{\mathrm{c}}$ & $5.57^{\mathrm{bc}}$ & $6.86^{\mathrm{a}}$ & $6.29^{\mathrm{ab}}$ & 0.34 & $* *$ \\
\hline Litter weight at weaning (g) & $2177^{\mathrm{c}}$ & $2198^{c}$ & $2514^{\mathrm{b}}$ & $2804^{\mathrm{a}}$ & 90.14 & $* *$ \\
\hline
\end{tabular}

Although there is a gradual increase in serum AST and ALT values in does fed gradual level of MTE, the differences were none significant and values were within normal rage (Table 5). In this connection, Ulger et al. (2017) found that adding $20 \mathrm{~g}$ silymarin/ head / day for Holstein cow did not affect AST and ALT activity. According to prolactin level in serum, does fed diet enriched with MTE at 3 and $6 \mathrm{ml} / \mathrm{kg}$ diet recorded the same improvement $(\mathrm{P} \leq 0.05)$ in prolactin value by $13.5 \%$ compared to control. Moreover, does fed 9MTE diet achieved significantly the highest value by $19.0 \%$ (Table 5). This improvement in prolactin value in tested groups may be due to anti-dopaminergic activity (Capasso, 2014) and the estrogenic effects (Demirci et al., 2014) of silymarin. In this respect, Capasso et al. (2009) and Capasso (2014) found that female rats administered with extracts of herbal galactagogues, such as Silitidil which is a standardized extract of milk thistle and Silymarin BIO-C (an extract from Silybum marianum fruits), increased serum prolactin levels significantly. Pituitary gland activate the secretion of prolactin hormone which in term increases two functions of the mammary glands such as the growth during pregnancy then stimulate of milk production during nursing infants (Ben-Jonathan et al., 2006). Recently, Mohammad et al. (2019) concluded that silymarin (which has galactogenic properties), increased serum prolactin levels in female rats during pregnancy and lactation.

Table (5): Effect of different levels of milk thistle seeds extract on does blood plasma constitutes.

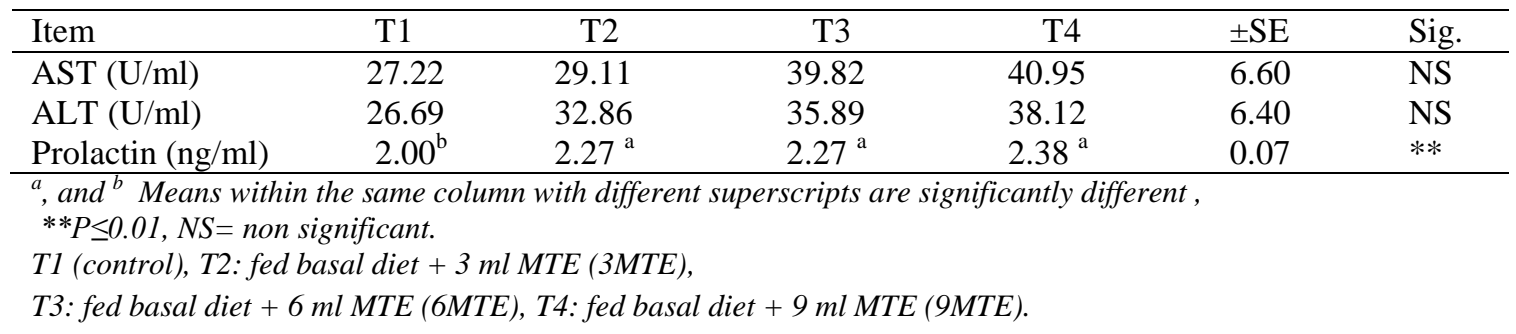

Regarding to milk composition (Table 6), doe rabbits fed either control or 9MTE diets recorded higher total protein and albumin values than others fed 3MTE (T2) and 6 MTE (T3), while, globulin and A/G ratio values were not affected significantly by any of the tested diets. These results disagree with the finding of Ulger et al. (2017) who concluded that treated Holstein dairy cattle with $20 \mathrm{~g}$ silymarin/head/day, had a reduction in milk protein. Total lipids in milk were significantly higher in group fed 9MTE followed by control and 3MTE. However, the least value was recorded with 6MTE group. This finding may be due to that silymarin did not have a cholagogue effect (Saeed et al,. 2017) which mean that it is an agent to promote higher flow of bile and it reflect on high milk lipids. The current results conflict with previous research of Tedesco et al. (2004) who found that dairy cows orally taken $10 \mathrm{~g}$ silymarin/day did not show any effect on milk composition (protein and fat\%). In another study, Ulger et al. (2017) reported that milk fat was significantly decreased by supplementing dairy cattle ration with silymarin. 
Refaie et al.

Table (6): Effect of different levels of milk thistle seeds extract on does milk composition.

\begin{tabular}{lcccccc}
\hline Item & $\mathrm{T} 1$ & $\mathrm{~T} 2$ & $\mathrm{~T} 3$ & $\mathrm{~T} 4$ & \pm SE & Sig. \\
\hline Total protein $(\mathrm{g} / \mathrm{dl})$ & $13.94^{\mathrm{a}}$ & $11.32^{\mathrm{b}}$ & $11.20^{\mathrm{b}}$ & $12.50^{\mathrm{ab}}$ & 0.53 & $* *$ \\
Albumin $(\mathrm{g} / \mathrm{dl})$ & $8.65^{\mathrm{a}}$ & $6.20^{\mathrm{b}}$ & $6.63^{\mathrm{b}}$ & $7.27^{\mathrm{ab}}$ & 0.47 & $* *$ \\
Globulin (g/dl) & 5.29 & 5.12 & 4.57 & 5.23 & 0.21 & NS \\
A/G ratio & 1.63 & 1.23 & 1.45 & 1.40 & 0.10 & NS \\
Total lipids (mg/dl) & $1184.2^{\mathrm{b}}$ & $948.5^{\mathrm{bc}}$ & $907.3^{\mathrm{c}}$ & $1581.2^{\mathrm{a}}$ & 79.63 & $* *$ \\
\hline
\end{tabular}

${ }^{a},{ }^{b}$ and ${ }^{c}$ Means within the same column with different superscripts are significantly different,

$* * P \leq 0.01, N S=$ non significant.

T1 (control), T2: fed basal diet $+3 \mathrm{ml} M T E$ (3MTE),

T3: fed basal diet + $6 \mathrm{ml}$ MTE (6MTE), T4: fed basal diet + $9 \mathrm{ml}$ MTE (9MTE).

\section{CONCLUSION}

It can be concluded that feeding doe rabbits with diets enriched with milk thistle seeds extract has a great affects on milk production (galactogogues effect), and improve litter weight at birth and weaning.

\section{REFERENCES}

Agriculture Ministry Decree (1996). The standard properties for ingredients, feed additives and feed manufactured for animal and poultry. El-Wakaee El-Masria, Amirria Press, Cairo, Egypt.

Attiaa, Y. A., R. S. Hamed, F. Boverac, A. E. Abd El-Hamid, M. A. Al-Harthia and H. A. Shahba (2017). Semen quality, antioxidant status and reproductive performance of rabbits bucks fed milk thistle seeds and rosemary leaves. Animal Reproduction Science, 184: 178-186.

Ben-Jonathan, N.; E. R. Hugo and T. D. Brandebourg (2006). Focus on prolactin as a metabolic hormone. Trends. Endocrinol. Metab., 17: 110-116.

Cai, X. L.; D. N. Li; J. Q. Qiao; H. Z. Lian and S. K. Wang (2009). Determination of Silymarin Flavonoids by HPLC and LC-MS and Investigation of Extraction Rate of Silymarin in Silybum marianum Fruits by Boiling Water. Asian Journal of Chemistry. 21(1): 63-74.

Capasso, R. (2014). Effect of Silitidil, a standardized extract of milk thistle, on the serum prolactin levels in female rats. Natural Product Communications, 9: 943-944.

Capasso, R.; G. Aviello; F. Capasso; F. Savino; A. A. Izzo; F. Lembo and F. Borrelli (2009). Silymarin BIO-C, an extract from Silybum marianum fruits, induces hyperprolactinemia in intact female rats," Phytomedicine, 16(9): 839-844.

Debier, C.; J. Pottier; Ch. Goffe and Y. Larondelle (2005). Seventh International Workshop in the Biology of Lactation in Farm Animals. Livestock Production Sci., 98 (1): 135-147.

Demirci, B.; T. Dost; F. Gokalp and M. Birincioglu (2014). Silymarin improves vascular function of aged ovariectomized rats. Phytother. Res., 28: 868-872.

Di Pierro, F.; A. Callegari; D. Carotenuto and M. M. Tapia (2008). Clinical efficacy, safety and tolerability of BIO-C (micronized Silymarin) as a galactagogue. Acta Biomed. 79: 205 - 210.

Duncan, D.B. (1955). Multiple range and multiple F tests. Biometrics, 11: 1-42.

El-Sayiad, G. H. A.; A. A. M. Habeeb and A. M. El Maghawry (1994). A note on the effects of breed, stage of lactation and pregnancy status on milk composition of rabbits. Anim. Prod., 58, 153-157.

Forinash, A. B.; A. M. Yancey; K. N. Barnes and T. D. Myles (2012). The use of galactogogues in the breastfeeding mother," Annals of Pharmacotherapy, 46(10): 1392-1404. 
Fortun-Lamothe, L.; T. Gidenne; A. Lapanouse and J. De Dapper (2000). Technical note: an original system to separately control litter and female feed intake without modification of the mother-young relations. World Rabbit Sci., 8: 177-180.

Giese, L. A. (2001). Milk thistle and the treatment of hepatitis. Gastroenterol. Nurs. 24: 95- 97.

Gupta, O. P.; S. Sing; S. Bani; N. Sharma; S. Malhotra; B. D. Gupta; S. K. Banerjee and S. S. Handa (2000). Anti-inflammatory and anti-arthritic activities of silymarin acting through inhibition of 5lipoxygenase. Phytomedicine 7: 21- 24.

Handa, S. S. (2008). An overview of extraction techniques for medicinal and aromatic plants, pp. 21103. In S.S. Handa, S.P.S. Khanuja, G. Longo and D.D. Rakesh, (eds.). Extraction Technologies for Medicinal and Aromatic Plants, United Nations Industrial Development Organization and the International Centre for Science and High Technology, Trieste, Italy.

Jackson, P. C. (2010). Complementary and alternative methods of increasing breast milk supply for lactating mothers of infants in the NICU. Neonatal Netw., 29: 225-230. PMID: 20630837

Kletzky O. A; R. P. Marrs; W. F. Howard; W. McCormick; D. R. Mishell (1980). Prolactin synthesis and release during pregnancy and puerperium. Am. J. Obste.t Gynecol.,136: 545-50.

Kshirsagar, M.; V. Mahash; P. Srinivas and L. Mangala (2013). Evaluation of the protective effect of silymarin on doxorubicin induced chronic testicular toxicity in Rats. International Journal of Pharmacy and Biological Sciences, 4: 473 - 484.

Liebler, D. (1992). Peroxyl radical trapping reactions of $\alpha$-tocopherol in biomimetic systems. In: Packer, L. and Fuchs, J. Editors, Vitamin E in Health and Disease, Marcel Dekker, New York, pp. 85-97.

Lukefahr, S.; W. Hohenboken; P. Cheeke and N. Patton (1983). Characterization of straight bred and crossbred rabbits for milk production and associative traits. J. Animal Sci., 1100-1107.

Maertens, L.; J. Vanacker and J. De Coninck (2006). Milk yield and milk composition of 2 commercial hybrids and a selected strain fed a high- energy lactation diet. Proc. $18^{\text {th }}$ Hungarian Conference on Rabbit Production, Kaposvar 24 May 2006, 35-41.

Mohammad, B. I.; H. A. Alzamely; F. K. Al Gharrawi and H. A. Al-Aubaidy (2019). Milk Thistle Seed Extract Favorably Affects Lactation and Development of Mammary Gland in Female Rats. Egypt. J. Vet. Sci., 50 (1): 27-36.

Mortel, M. and S. D. Mehta (2013). Systematic review of the efficacy of herbal galactogogues. Journal of Human Lactation, 2(29): 154-162.

Nencini, C.; G. Giorgi and L. Micheli (2007). Protective effect of silymarin on oxidative stress in rat brain. Phytomedicine 14: 129-135.

Pascual, J. J.; W. Motta; C. Cervera; F. Quevedo; E. Blas and J. F. Carmona (2002). Effect of dietary energy source on the performance and perirenal fat thickness evolution of primiparous rabbit does. Anim. Sci., 75, 267-279.

Reitman, S. and S. Frankel (1957). Determination of GOT and GPT. Amr. J. Clin. Path., 28:56-63.

Rochambeau, H. (1998). The parental female from the experimental strains of INRA: genetic evolutions and perspectives. Proc. 7th Journ. Rech. Cunicole, Lyon, France, ITAVI Ed., 3-14.

Saeed, M.; D. Babazadeh; M. Arif; M. A. Arain; Z. A. Bhutto; A. H. Shar; M. U. Kakar; R. Manzoor and S. Chao (2017). Silymarin: a potent hepatoprotective agent in poultry industry. Worlds Poult Sci J. 73(3):483-492.

SAS (2001). Statistical Analysis System User's Guide Version 8.2, Cary NC. USA.

Szendrö, Zs. and L. Maertens (2001). Maternal effect during pregnancy and lactation in rabbits (a review). Acta Agraria Kaposváriensis, 5 (2): 1-21.

Taher, M. A.; Y. A. Atia and M. K. Amin (2012). Improving an Ovulation Rate in Women with Polycystic Ovary Syndrome by Using Silymarin. Global Journal of Medical Research. 12(6): 15-21.

Tedesco, D.; A. Tava; S. Galletti; M. Tameni; G. Varisco; A. Costa and S. Steidler (2004). Effects of silymarin, a natural hepatoprotector, in periparturient dairy cows. J. Dairy Sci. 87: 2239 - 2247. 


\title{
Refaie et al.
}

Tudela, F.; J. Hurtaud; H. Garreau and H. De Rochambeau (2003). Comparison of the zootechnical performance of parental females from a control strain and a strain selected for numerical productivity. In Proc.: 10th Journ. Rech. Cunicole, Paris, ITAVI Ed., Paris, 53-56.

Ulger, I.; A. C. Onmaz and T. Ayaşan (2017). Effects of silymarin (Silybum marianum) supplementation on milk and blood parameters of dairy cattle. South African Journal of Animal Science, 47 (6): 758 765 .

Zapantis, A.; J. G. Steinberg and L. Schilit (2012). Use of herbals as galactagogues. Journal of Pharmacy Practice, 2(25): 222-231.

\section{تأثير اضافة مستخلص حليب الشوك للعلائق على الاداء الانتاجى لامهات الارانب}

\author{
أميره محمود رفاعى ، مرفت نبيل غزال ، عنايات ابو العزايم و مروى حسنى عبد المجيد \\ معطج بحوث الانتاج الحيوانى - مركز البحوث الزراعية - الجيزة- مصر.
}

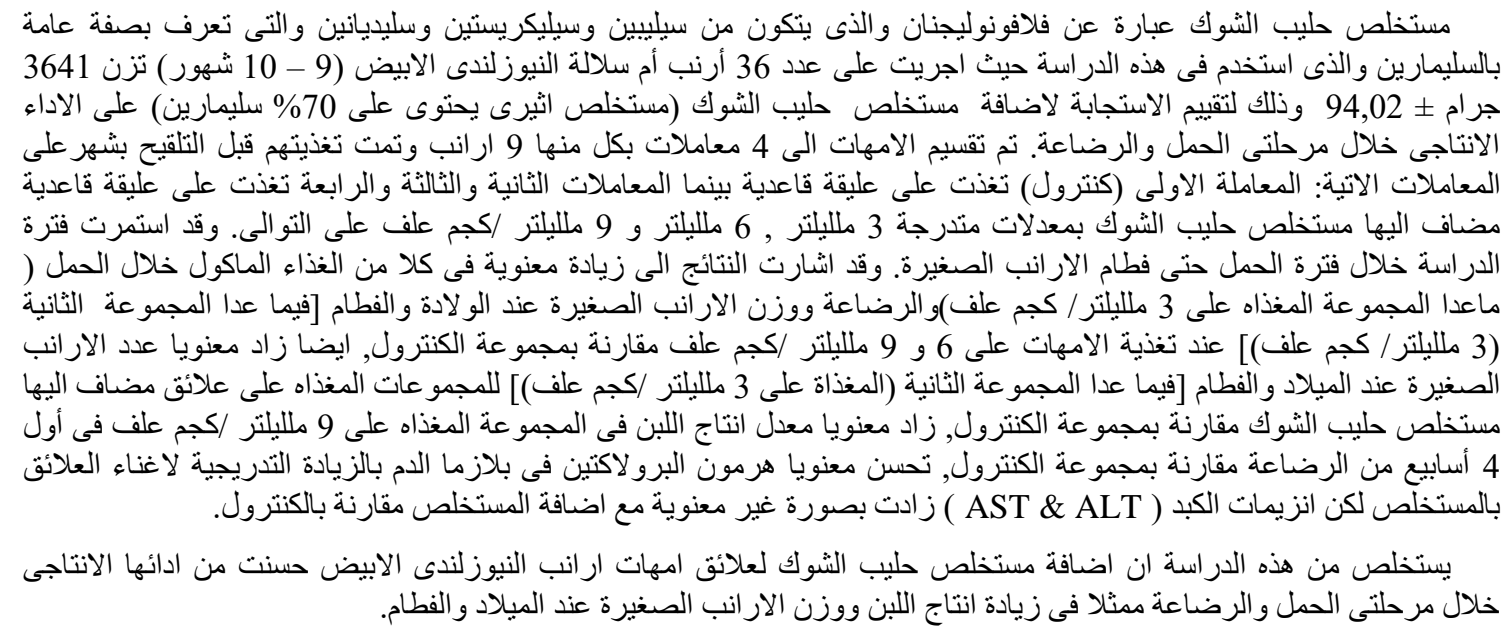

